\title{
DIFFERENTIAL AGGLUTINATION TEST IN RHEUMATOID ARTHRITIS COMPLICATED BY PNEUMOCONIOSIS
}

\author{
BY \\ JOHN BALL \\ From the Rheumatism Research Centre, University of Manchester
}

(RECEIVED FOR PUBLICATION JANUARY 18, 1955)

During a survey of rheumatoid arthritis in a South Wales mining valley (Miall and others, 1953; Miall, 1955), the differential agglutination test (D.A.T.) was adopted as one of the diagnostic criteria of this syndrome. One of the principal objects of the survey was the further investigation of the observation of Caplan (1953) of an association between an unusual form of progressive massive pulmonary fibrosis (P.M.F.) and rheumatoid arthritis; the serological data obtained during the survey are presented here and discussed with particular reference to this problem of the association of pulmonary disease and rheumatoid arthritis in miners.

\section{Methods}

The technique used in performing the D.A.T. has been previously described (Ball, 1950). In the present study a serum was accepted as positive if agglutination to a titre of $1: 32$ or more was observed when the test was read after $18 \mathrm{hrs}$. The sensitivity of the test was kept constant by using a series of human sera of known agglutinating activity as standards with which the appropriate dilution of different batches of anti-sheep rabbit serum could be determined.

The cases of rheumatoid arthritis were divided into three types according to the following clinical and radiological data provided by Dr. W. E. Miall.

Type 1.-Cases with a characteristic clinical history, definite residual clinical signs, and radiological evidence of rheumatoid disease.

Type 2.-Cases with a characteristic history and residual signs but with no definite radiological abnormality.

Type 3.-Cases with a characteristic history but with neither residual symptoms, signs, or radiological abnormality.
These criteria are less strict than those adopted in the epidemiological studies (Miall, 1955) and probably allow the inclusion of some doubtful cases. Serological and chest $x$-ray findings were available for all but three of the 78 cases of rheumatoid arthritis detected in the survey. Among the 75 cases accepted for analysis, $x$ rays of the limbs were not available in three; two of these had P.M.F. and were bed-ridden with rheumatoid arthritis and have therefore been accepted as Type 1 cases. The remaining case had a Caplan chest $x$ ray and a characteristic history of rheumatoid arthritis, but the residual signs of this disease were limited to one elbow; this case was placed in the Type 2 group.

\section{Results}

The D.A.T. results in the 75 cases are presented in Table I according to the chest $x$-ray findings and the clinical type of rheumatoid arthritis. There is suggestive evidence in this table that among cases of either Caplan's syndrome, P.M.F., or tuberculosis positive tests will be observed more frequently than in cases with either a normal chest or with simple pneumoconiosis.

Previous work has shown that the results obtained with the D.A.T. are positively correlated with the severity and duration of the arthritis and with the presence of subcutaneous nodules. A comparison of the arthritis in the various chest disease groups was made by assessing the severity of the disease according to the proportion of Type 1 cases and the duration of the disease according to the proportion of cases with a duration of over 3 years respectively. To facilitate analysis, the combined normal and simple pneumoconiosis cases have been grouped for

TABLE I

RELATION OF TEST TO CLINICAL TYPES OF RHEUMATOID ARTHRITIS AND THE CHEST $X$-RAY FINDINGS

\begin{tabular}{|c|c|c|c|c|c|c|c|c|c|c|c|c|}
\hline \multirow{3}{*}{\multicolumn{2}{|c|}{$\begin{array}{c}\text { Clinical Type of } \\
\text { Rheumatoid Arthritis }\end{array}$}} & \multicolumn{11}{|c|}{ Chest $X$-Ray Findings } \\
\hline & & \multicolumn{2}{|c|}{ Normal } & \multicolumn{2}{|c|}{$\begin{array}{c}\text { Simple } \\
\text { Pneumoconiosis }\end{array}$} & \multicolumn{2}{|c|}{ Tuberculosis } & \multicolumn{2}{|c|}{$\begin{array}{l}\text { Massive } \\
\text { Fibrosis }\end{array}$} & \multicolumn{2}{|c|}{ Caplan's } & \multirow{2}{*}{$\begin{array}{c}\text { Total } \\
\text { No. of } \\
\text { Cases }\end{array}$} \\
\hline & & +ve & Total & + ve & Total & $+\mathrm{ve}$ & Total & + ve & Total & $+v e$ & Total & \\
\hline \multicolumn{2}{|c|}{$\begin{array}{l}1 \\
2 \\
3\end{array}$} & $\begin{array}{l}8 \\
2 \\
1\end{array}$ & $\begin{array}{r}14 \\
2 \\
7\end{array}$ & $\begin{array}{l}1 \\
0 \\
2\end{array}$ & $\begin{array}{l}3 \\
1 \\
2\end{array}$ & $\begin{array}{r}10 \\
0 \\
1\end{array}$ & $\begin{array}{r}11 \\
1 \\
2\end{array}$ & $\begin{array}{l}9 \\
1 \\
0\end{array}$ & $\begin{array}{l}9 \\
3 \\
1\end{array}$ & $\begin{array}{r}11 \\
3 \\
4\end{array}$ & $\begin{array}{r}12 \\
3 \\
4\end{array}$ & $\begin{array}{l}49 \\
10 \\
16\end{array}$ \\
\hline Total & . & 11 & 23 & 3 & 6 & 11 & 14 & 10 & 13 & 18 & 19 & 75 \\
\hline
\end{tabular}


comparison with cases of tuberculosis and the combined cases of P.M.F. and Caplan's syndrome.

Tables II and III show that, in respect of these features of the arthritis, the normal and simple pneumoconiosis group is closely similar to the P.M.F. and Caplan group; and any differences in the serological results may therefore be reasonably related to the accompanying chest $x$-ray finding. In the tuberculosis group, however, the arthritis was apparently more severe in general and, in all but one case, had been present for more than 3 years.

TABLE II

CHEST $X$-RAY FINDINGS RELATED TO TYPE OF RHEUMATOID ARTHRITIS

\begin{tabular}{|c|c|c|c|}
\hline \multirow{2}{*}{ Chest $X$-Ray Findings } & \multicolumn{3}{|c|}{ Rheumatoid Arthritis } \\
\hline & Type 1 & Types 2 and 3 & Total \\
\hline $\begin{array}{c}\text { Normal and Simple Pneumo- } \\
\text { coniosis }\end{array}$ & 17 & 12 & 29 \\
\hline Tuberculosis. . & 11 & 3 & 14 \\
\hline $\begin{array}{c}\text { Massive Fibrosis and } \\
\text { Caplan's .. }\end{array}$ & 21 & 11 & 32 \\
\hline Total & 49 & 26 & 75 \\
\hline
\end{tabular}

TABLE III

CHEST $X$-RAY FINDINGS RELATED TO DURATION OF RHEUMATOID ARTHRITIS

\begin{tabular}{|c|c|c|c|}
\hline \multirow{2}{*}{ Chest $X$-Ray Findings } & \multicolumn{3}{|c|}{ Rheumatoid Arthritis } \\
\hline & Over 3 yrs & Up to $3 \mathrm{yrs}$ & Total \\
\hline $\begin{array}{c}\text { Normal and Simple Pneumo- } \\
\text { coniosis }\end{array}$ & 20 & 9 & 29 \\
\hline Tuberculosis. . & 13 & 1 & 14 \\
\hline $\begin{array}{l}\text { Massive Fibrosis and } \\
\text { Caplan's .. }\end{array}$ & 20 & 12 & 32 \\
\hline Total & 53 & 22 & 75 \\
\hline
\end{tabular}

A $\chi^{2}$-test indicates that these variations between the tuberculosis group and the normal and pneumoconiosis group might have arisen by chance $(P>0 \cdot 1$ for duration, $P>0.5$ for severity), but in view of the small sample available it is difficult to be certain of this. Moreover, there is some evidence (Cobb and others, 1953; and unpublished personal observations) that infections of all kinds are a notable cause of death in hospital cases of rheumatoid arthritis; and the possibility exists that subjects with severe rheumatoid disease may be prone to tuberculosis. If so, one would expect to find a relatively severe type of arthritis in cases of tuberculosis. Until a larger group of such cases has been examined, it is therefore considered advisable to confine the analysis of the serological results to a comparison of the normal and pneumoconiosis group with the P.M.F. and Caplan group (Table IV).
TABLE IV

CHEST $X$-RAY FINDINGS RELATED TO RESULT OF D.A.T. POSITIVE $=$ RECIPROCAL OF TITRE $>32$

\begin{tabular}{|c|c|c|c|}
\hline \multirow{2}{*}{ Chest $X$-Ray Findings } & \multicolumn{3}{|c|}{ D.A.T. Result } \\
\hline & Positive & Negative & Total \\
\hline $\begin{array}{l}\text { Normal and Simple Pneumo- } \\
\text { coniosis } \\
\text { con }\end{array}$ & 14 & 15 & 29 \\
\hline $\begin{array}{l}\text { Massive Fibrosis and } \\
\text { Caplan's } \ldots\end{array}$ & 28 & 4 & 32 \\
\hline Total & 42 & 19 & 61 \\
\hline
\end{tabular}

Table IV shows that there is a definite correlation between the result of the test and the chest $x$-ray finding, the incidence of positive tests being greater among cases of massive fibrosis. This serological difference between the two groups is equally striking if the actual titres at $18 \mathrm{hrs}$ are compared (Table V, and Figure).

The titres, ranging from $1 /<4$ to $1 / 1,024$, are grouped into "low" and "high" responses in Table V.

TABLE $\mathrm{V}$

CHEST $X$-RAY FINDINGS RELATED TO D.A.T RESPONSE WITH RECIPROCAL OF TITRE $\leqslant 64$ AND $>128$

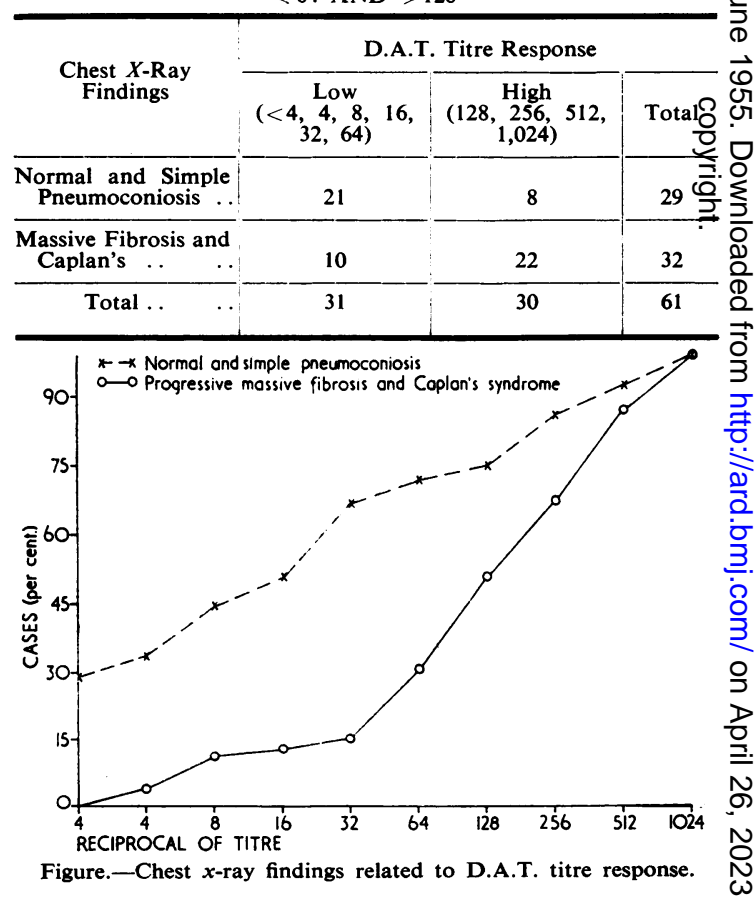

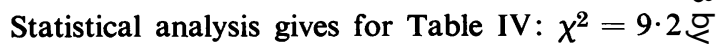
and $P=<0.01$; and for Table $V: \chi^{2}=8.8$ ando $P=<0.01$. If a titre of $1 / 64$ is included in the $\mathbb{\Phi}$ "high" responses, $\chi^{2}$ becomes 15.8 and $P=<0.001$. ? It may therefore be concluded that, in these cases of $\underline{T}$ rheumatoid arthritis, the appearance of the rheuma- 
toid serum factor in relatively high titres is much more likely in the presence of a severe progressive nodular type of pneumoconiosis than in subjects with a normal chest or with simple pneumoconiosis.

\section{Discussion}

Although the precise nature and origin of the rheumatoid serum factor (R.S.F.) agglutinating sensitized sheep cells is not known, its occurrence in high titre is probably confined to rheumatoid arthritis and certain closely related syndromes such as disseminated lupus erythematosus (Ball, 1952). Other conditions in which arthritis and constitutional disturbances occur, such as ankylosing spondylitis and rheumatic fever, are negative in the agglutination test. It is also known that the R.S.F. does not reflect variations in the clinical state of rheumatoid arthritis, since the titre may remain high during a natural or therapeutically induced clinical remission. Presumably the R.S.F. is related to a type of tissue response characteristic of rheumatoid arthritis but not closely linked with the constitutional and arthritic manifestations of this disease. Nevertheless, the D.A.T. is most frequently positive in severe classical cases of long duration in which subcutaneous nodules are found.

The present studies show that among subjects with rheumatoid arthritis, both the incidence of positive tests and the titre of the R.S.F. are higher in those with P.M.F. than in those with simple pneumoconiosis or a normal chest $x$ ray. Moreover, this difference is not likely to be due to variations in the severity or duration of the rheumatoid arthritis in the various chest disease groups.

The serological results in the P.M.F. group, though not so striking as those of the Caplan group, show the same trend; and it is probable that the presence of massive fibrosis of either type modifies, in some as yet undetermined way, the results obtained with the D.A.T. in subjects with rheumatoid arthritis. Several possible explanations of this finding may be considered:

(1) Subjects whose rheumatoid arthritis is associated with a positive D.A.T. may be more susceptible to P.M.F. than those with a negative D.A.T.

(2) P.M.F. may itself be associated in a proportion of cases with a positive D.A.T. in the absence of arthritis.

(3) The presence of pulmonary tuberculosis which is believed to be an important factor in the pathogenesis of P.M.F. may modify the serological response to rheumatoid arthritis.

At present it is not possible to suggest which, if any, of these possibilities apply. The matter is being further investigated by the serological exami- nation of various non-arthritic control groups, the results of which it is hoped to publish in due course.

\section{Summary}

(1) In a sample of rheumatoid arthritis defined by Miall (1955) in an epidemiological study of this disease in a South Wales mining valley, the results of the differential agglutination test were found to vary according to the chest $x$-ray finding.

(2) Both the incidence of positive tests and the titres were higher in subjects with progressive massive pulmonary fibrosis (P.M.F.) than in those with simple pneumoconiosis or a normal chest $x$ ray.

(3) This difference was not explained by variations in the severity or duration of the rheumatoid disease in the various chest disease groups.

I am grateful to Professor J. H. Kellgren and to Drs. J. C. Gilson, A. L. Cochrane, and W. E. Miall for their interest and advice.

\section{REFERENCES}

Ball, J. (1950). Lancet, 2, 520.

(1952). Annals of the Rheumatic Diseases, 11, 97.

Caplan, A. (1953). Thorax, 8, 29.

Cobb, S., Anderson, F., and Bauer, W. (1953). Proc. Ann. Meet. Amer. Rheum. Ass., Annals of the Rheumatic Diseases, $12,323$.

Miall, W. E. (1955). Ibid., 14, 150.

-, Caplan, A., Cochrane, A. L., Kilpatrick, G. S., and Oldham, P. D. (1953). Brit. med. J., 2, 1231.

Réaction d'agglutination différentielle dans l'arthrite rhumatismale compliquée de pneumoconiose

\section{RÉSUMÉ}

(1) Chez un groupe de rhumatisants arthritiques, définis par Miall (1955) au cours de l'étude épidémiologique de cette maladie dans une vallée minière des Galles du Sud, on a trouvé que les résultats de la réaction d'agglutination différentielle variaient selon l'image radiologique de la poitrine.

(2) Aussi bien la fréquence que les titres des résultats positifs étaient plus élevés chez les sujets atteints de fibrose pulmonaire massive et progressive (P.M.F.) que chez les sujets à l'image radiologique normal ou atteints de pneumoconiose simple.

(3) Les variations de la sévérité ou de la durée de la maladie rhumatismale dans les groupes différents de maladie pulmonaire $n$ 'expliquent pas cette différence.

Reacción de aglutinación diferencial en la artritis reumatoide complicada de pneumoconiosis

\section{Sumario}

(1) En un grupo de enfermos con artritis reumatoide, definidos por Miall (1955) en el estudio epidemiológico de esta enfermedad en la cuenca minera de las Gales del Sur, la reacción de aglutinación diferencial varía según el aspecto radiológico del pecho.

(2) Tanto la frecuencia como la intensidad de los resultados positivos fueron mayores en sujetos con fibrosis pulmonar masiva y progresiva (P.M.F.) que en sujetos con pneumoconiosis simple o con radiología pulmonar normal.

(3) Las variaciones de la severidad o de la duración de la enfermedad reumática en los varios grupos de enfermedad pulmonar no explican esta diferencia. 